\title{
STRATEGI SURAT KABAR RADAR DEPOK DALAM MENGANTISIPASI MEDIA ONLINE
}

\author{
SITIANA NURHASANAH \& JUFRI ALKATIRI \\ Fakultas IImu Komunikasi Univervitas Pancasila \\ Email: alkatirijufri@gmail.com
}

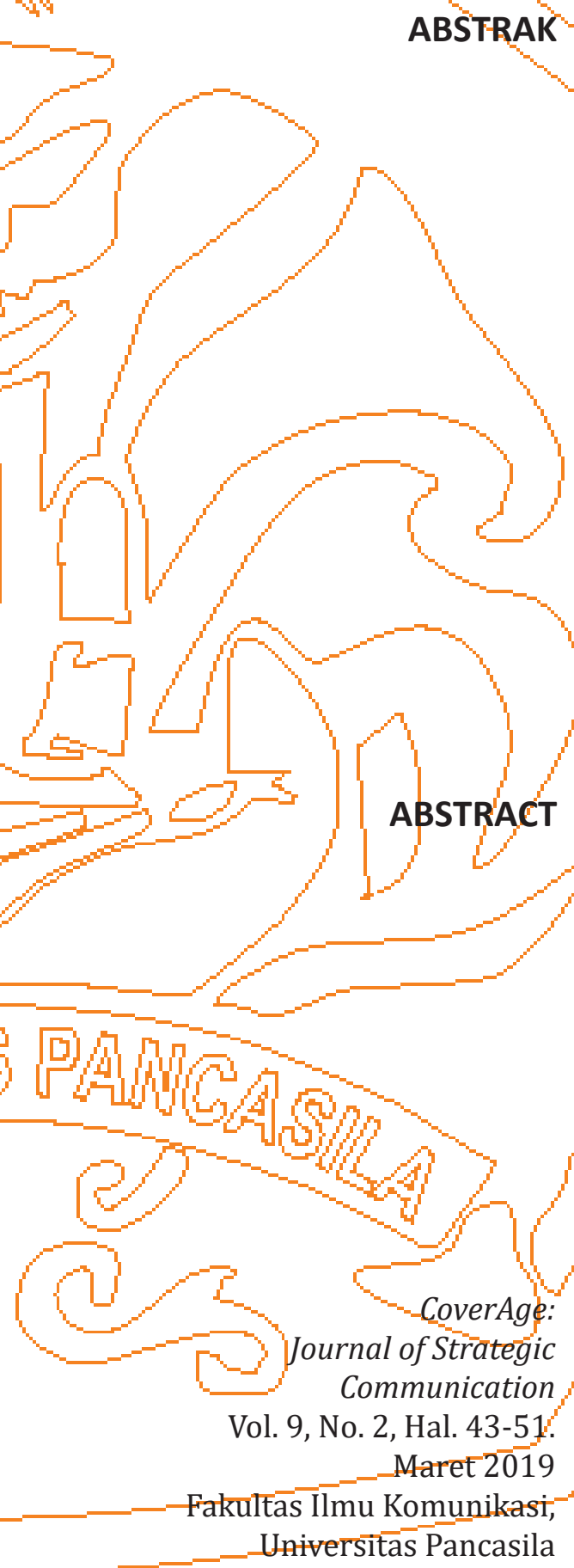

Tujuan penelitian ini untuk mengetahui upaya surat kabar Radar Depok yang dapat mempertahankan eksistensinya serta mengantisipasi persaingannya di industri medià khususnya pada era media online saat ini. Kajian konsep yang digunakan adalah strategi media massa, dan media massa (surat kabar, media online). Paradigma penelitian adalah post-positivis, pendekatan penelitian adalah kualitatif. Unit analisisnya adalah individu yaitu redaktur pelaksana Radar Depok, dan jurnalis senior. Teknik pengumpulan data menggunakan wawancara mendalam, observasi non-partisipan dan dokumentasi, serta keabsahan data menggunakan teknik triangulasi sumber. Hasil penelitian ini menunjukkan bahwa bagi Radar Depok media online bukanlah sebuah ancaman yang besar karena menurutnya Radar Depok sudah memiliki' pasarnya tersendiri. Strategi pada Radar Depok yaitu melakukan inovasi visual, memuat rubrik-rubrik terbaru dengan moment tertentu, dan memiliki media online. Bagi Radar Depok, upaya strategi yang dilakukan bertujuan untuk tetap mempertahankan pelanggannya agar tidak berkurang, serta strategi yang sudah dilakukan semua diharapkan dapat menarik perhatian pembaca baru surat kabar Radar Depok.

Kata Kunci: Strategi media, surat kabar, media online.

The purpose of this study is to determine the efforts of the Depok Radar newspaper that can maintain its existence and anticipate competition in the media industry, especially in the curreht online media era. The concept studies used are mass media strategies and mass media (newspapers, online media). The research paradigm is post-positivist, the research approach is qualitative. The unit of analysis is individuals namely managing editor Radar Depok, and senior journalists. Data collection techniques using in-depth interviews, non-participant observation and documentation, as well as the validity of the data using source triangulation techniques. The results of this study indicate that for Radar Depok online media is not a big threat because according to him Radar Depok already has its own market. The strategy at Radar Depok is to do visual innovation, load the latest rubrics with specific moments, and have online media. For Radar Depok, the strategy efforts undertakeh are aimed at maintaining its customers so as not to decrease, and the strategies that have been carried out are all expected to attract the attention of new readers of the Radar Depok newspaper.

Keywords: Media strategy, newspaper, online media. 


\section{PENDAHULUAN}

Tren oplah media cetak sejak 2008 hingga 2014 menunjukan kenaikan, tetapi selama masa tersebut perkembangan media memang selalu naik turun. Saat 2008 total oplah harian berjumlah 7,49 juta, angka ini terus meningkat walaupun jarak angkanya tidak terlalu signifikan akan tetapi terus naik. Pada puncaknya yaitu tahun 2014, total oplah media cetak telah mencapai 9,65 juta. Kenaikan itu tidak terjadi pada tahun 2015, ketika itulah oplah terjun bebas menjadi 8,79 juta. Terjadinya pemerosotan oplah pada media cetak ini paling banter menimpa pada tabloid mingguan atau majalah (Sumadiria, 2014: 42).

Tahun 2015 ada koran Indonesia yang menyatakan tutup, yaitu Sinar Harapan. Media ini sudah dikenal sebagai koran tertua dan eksis serta mencatat sejarah perjalanan Indonesia, karena terbit perdana sejak 1961. Tutupnya Sinar Harapan karena atas dasar permintaan investor yang beranggapan dan menilai surat kabar ini tidak memberikan keuntungan secara ekonomi, adapun surat kabar lainnya yang tutup seperti Jakarta Globe, Koran Tempo Minggu, Harian Jurnal Nasional. Beberapa media cetak lainnya seperti majalah dan tabloid juga banyak yang mengalami hal sama, yaitu banyak yang tidak terbit lagi atau sudah tutup.

Menurut data Nielsen Indonesia pada September 2017, pada awal tahun belanja iklan mengalami peningkatan yaitu sebesar $6 \%$. Pada keseluruhan total belanja, koran lebih kecil dibanding media elektronik yaitu televisi. Belanja pada iklan di koran yang minim membuat banyak koran semakin resah, serta bermunculan peramalan akannya banyak koran yang akan gulung tikar. Mereka tidak mampu bertahan di industri media cetak karena adanya persaingan dengan media online. Jumlah pembaca koran yang saat ini terus turun bukan menghilang, mereka hanya pindah platform. Banyaknya masyarakat yang pindah platform ke digital dikarenakan media online lebih praktis serta setiap orang bisa mendapatkan informasi kapanpun dan di mana pun tanpa harus membawa koran yang kurang praktis.

Merujuk data Nielsen Indonesia tahun 2017, turunnya minat pembaca media cetak di Indonesia yaitu minat pembaca media cetak sudah kalah banyak dari media online. Pada tahun 2017 kebiasaan membaca yang dilakukan oleh orang Indonesia sudah mengalami pergeseran. Tingkat pembelian koran secara personal hanya $20 \%$, berbeda dengan tahun 2013 yaitu sebesar $28 \%$. Saat ini media cetak hanya menjadi pilihan kelima bagi masyarakat Indonesia untuk mendapat sebuah informasi maupun berita dengan penetrasi sebesar $8 \%$. Pilihan pertama yaitu televisi dengan $96 \%$, kedua papan iklan jalan dengan 52\%, ketiga masyarakat dengan penggunaan internet yaitu $43 \%$, dan keempat radio dengan $37 \%$.

Demi mempertahankan eksistensinya dan persaingannya di industri media, semakin banyak surat kabar yang membuat platform onlinenya. Tidak sedikit pula banyak surat kabar yang menutup media cetaknya dan beralih ke media online. Melalui media online, setiap khalayak dapat mengakses berbagai informasi tanpa batasan ruang dan waktu.

Inovasi ini dibutuhkan agar media massa seperti surat kabar mampu tetap bersaing di era bisnis saat ini. Saling adanya hubungan antara surat kabar dan media online, akan mungkin adanya perluasan. Perluasan tersebut antara lain perluasan jaringan, perluasan khalayak, dan perluasan interaksi yang muncul. Informasi akan mengalir lebih cepat dan fleksibel dengan adanya media online.

Media online bukan saja memperlihatkan perkembangan teknologi yang begitu cepat dan canggih. Tetapi mengubah hubungan antara teknologi, industri, pasar, gaya hidup dan khalayak. Dengan bentuknya yang digital, tidak perlu lagi mengeluarkan biaya produksi tinggi untuk membeli kertas, cukup dalam bentuk digital yang hampir nol biaya produksi.

Hanya saja saat ini, banyaknya media online dengan jumlah puluhan ribu masih banyak yang belum terverifikasi. Ini menyebabkan adanya oknum-oknum yang asal dalam memberikan informasi serta menyebarluaskan dengan pemberitaan yang belum tentu benar atau hoax. Seperti yang dikatakan oleh Dewan Pers, pada tahun 2018 total jumlah media online yang ada di Indonesia sudah mencapai sekitar 43.000 media. Dari kesulurahan media tersebut yang terdata di Dewan Pers hanya sekitar 130 media online.

Penting adanya verifikasi bagi suatu media online agar media tersebut selain cepat dalam menaikkan berita, ia juga tetap menyajikan informasi yang faktual dan obyektif. Verifikasi ini juga bertujuan agar seluruh masyarakat dapat memilih dan menyaring media mana yang 
semestinya harus diakses dan mana yang tidak, karena saat ini sudah banyak media-media yang tidak bertanggungjawab dalam menginformasikan sebuah berita yang menyebabkan terjadinya isu hoax yang dapat merugikan semua pihak.

Di Indonesia, ada beberapa media cetak yang masih bertahan menerbitkan koran hariannya seperti salah satunya pada Radar Depok. Radar Depok merupakan media yang bergerak pada media cetak tetapi saat ini ia telah memiliki platform online juga, hal tersebut adalah salah satu upaya yang dilakukan untuk mengantisipasi di era media online saat ini. Media ini berdiri sejak 15 Juli 2010 bertepatan dengan dapil kota Depok. Pada saat berdirinya tersebut, Radar Depok sudah masuk ke dalam bagian dari Jawa Pos Group \& Radar Bogor Group. Hadirnya surat kabar Radar Depok bertujuan untuk memberikan warna berbeda di Kota Depok. Dengan tagline "Depok Sesungguhnya" surat kabar ini menampilkan 95\% berita tentang Kota Depok dan lainnya berita tentang internasional dan nasional. Berita yang disajikan oleh Radar Depok pun bervariasi, mulai dari politik, olahraga, kriminal, tentang kemasyarakatan, bencana alam, dan lainnya.

Koran Radar Depok merupakan surat kabar lokal di mana surat kabar ini mencerminkan keadaan dari kota tersebut. Seluruhnya mencakup pemberitaan serta membahas informasi dari wilayah itu sendiri. Dalam surat kabar ini isi yang terdapat $80 \%$ laporan, tulisan, serta gambar dengan nuansa lokal kota tersebut (Sumadiria, 2014: 42).

\section{TINJAUAN PUSTAKA}

\section{Strategi Media Massa}

Strategi merupakan pendekatan secara menyeluruh yang berkaitan dengan suatu pelaksanaan gagasan dan perencanaan dalam jangka waktu tertentu. Adapun strategi ini yaitu proses penentuan rencana dalam jangka waktu panjang dan di dalamnya terdapat penyusunan suatu upaya agar tujuan dapat dicapai. Seperti yang dijelaskan David dalam bukunya, strategi merupakan suatu perencanaan dengan fokus jangka waktu panjang yang akan dicapai. Strategi ini juga mencakup pengembangan produk dan penetrasi pasar (David, 2011: 18-19).

Perusahaan dapat mencapai suatu tujuan karena adanya rencana yang telah dirancang sebelumnya. Rencana yang dilakukan adalah dengan membuat strategi-strategi yang komprehensif (Rangkuti, 2013: 183). Dalam kata lain, strategi di sini merupakan perencanaan yang bersifat lengkap dan luas. Mempunyai dan memperlihatkan wawasan yang luas juga di perlukan dalam menyusun strategi.

Sedangkan Pearce II dan Robinson menjelaskan bahwa strategi merupakan suatu rencana dengan skala yang besar, menentukan arah ke depannya akan seperti apa, yang ditujukan untuk berinteraksi dengan kondisi persaingan untuk mencapai tujuan perusahaan (Pearce II \& Robinson, 2008: 2). Dapat disimpulkan bahwa strategi di sini merupakan suatu susunan rencana yang dilakukan secara terus menerus demi mencapai target yang akan dicapai dalam persaingan yang ada.

Menurut Hafid Cangara, (Cangara 2010: 123126), media cetak sebuah alat yang digunakan untuk menyampaikan pesan-pesan dari sumber kepada masyarakat secara langsung. Media cetak menjadi sebuah hal yang juga setara dengan televisi, radio, dan lain sebagainya. Namun media cetak disampaikan dengan cara fisik dan secara langsung dengan bacaan. Selain itu menurut Santana, setiap surat kabar menyajikan suatu berita yang selalu memberikan informasi perkembangan apapun yang terjadi di masyarakat. Suatu berita yang mendalam menjadi ciri khas yang dimiliki surat kabar ketika hadir di tengah masyarakat (Santana, 2017: 167).

Meskipun di tengah terjang era media online pada saat ini, di zaman yang menuntut untuk segala akses yang mudah dan praktis. Ternyata surat kabar tetap mampu menahan eksistensinya dikalangan masyarakat. Banyak faktor dan pengaruh yang menjadikan surat kabar tetap bertahan dipasaran sampai saat ini. Dalam mendapatkan informasi, seorang pencari informasi atau pembaca haruslah mampu dan mendapatkan informasi yang tepat dan akurat serta menjunjung profesionalitas. Hal itu yang selalu menjadi prioritas mengalahkan akses instan dan teknologi canggih sekalipun.

Perusahaan media cetak harus mempertahankan eksistensinya agar semua orang tetap berminat untuk membaca sebuah informasi melalui media cetak. Eksistensi adalah keberadaan, kehadiran yang mengandung unsur bertahan. Begitu juga dengan media pada tahap ini, perusahaan dapat melakukan berbagai strategi. Pertama, menghasilkan produk baru karena produk-produk tertentu akan mati. Karena produkproduk yang tidak perlu harus dibuang dan diganti. 
Perusahaan harus bisa mendapatkan keuntungan dari produk-produk baru pemilihan produk, definisi dan desain harus dilakukan secara terus-menerus (Heizer \& Render, 2009:4).

Kedua, strategi modifikasi produk. Cara ini dapat membuat perusahaan membangkitkan pemasaran dengan modifikasi produk melalui perbaikan kualitas, perbaikan fitur, atau perbaikan gaya. Peningkatan kualitas produk bertujuan untuk meningkatkan kinerja fungsional produk. Demikian pula perbaikan fitur-fitur baru pada produk itu. Strategi ini mempunyai beberapa keunggulan. Fiturfitur baru membangun citra perusahaan sebagai inovator dan memenangkan loyalitas segmen pasar yang menghargai fitur-fitur itu. Perbaikan gaya bertujuan meningkatkan daya tarik estetik produk (Kotler \& Keller, 2011: 266).

\section{Manajemen Media Massa}

Manajemen merupakan cara dari suatu organisasi untuk mencapai hasil yang diinginkan dan membuat dorongan agar melakukan kinerja dengan total, manajemen ini dapat berupa pengarahan dan pengordinasian (Morissan, 2008: 136). Sedangkan menurut (Terry \& Rue, 2015: 1) manajemen adalah proses yang berkaitan dengan pengarahan dan bimbingan kelompok di mana orang-orangnya mengarah pada tujuan organisasi yang jelas serta di dalam kegiatannya terdapat suatu pelaksanaan. Menurut (Morissan, 2008: 138), terdapat empat fungsi dasar dari manajemen, yaitu: Perencanaan -merupakan penentuan strategi yang digunakan agar tujuan tersebut tercapai.

Pengorganisasian adalah suatu proses penyusunan struktur organisasi sesuai dengan tujuan organisasinya. Pengarahan dan memberikan pengaruh -- bertujuan pada upaya untuk membuat karyawan lebih antusias agar melaksanakan tanggung jawabnya masing-masing secara efektif. Selain itu, ada pengawasan, seperti evaluasi yang diadakan secara keseluruhan oleh anggota organisasi lalu dibahas apakah perencanaan yang sudah dirancang sudah mencapai tujuan atau belum, setelah itu diberikan penilaian dan perbaikan pada setiap kinerjanya. Jadi, empat fungsi dasar manajemen merupakan tahapan berjalannya suatu rencana atau strategi yang dibuat oleh organisasi maupun perusahaan. Adanya manajemen atau pengelolaan ini karena untuk mencapai tujuan organisasi. Tahapan awal dimulai dari perencanaan dan berakhir dengan pengawasan atau evaluasi dari pelaksanaan yang sudah dijalankan.

Media massa merupakan sarana atau alat untuk menyampaikan suatu informasi, di mana setiap orang dapat mengakses dan menggunakannya secara lebih luas (Tamburaka, 2012: 13). Selain itu, media massa juga merupakan suatu alat untuk penyampaian pesan dari komunikator kepada khalayak yaitu dengan cara menggunakan alat komunikasi seperti televisi, radio, dan surat kabar (Cangara, 2010: 123-126). Di media massa, ada empat elemen utama dalam kehidupan masyarakat (McQuail, 2011:26), yaitu: Tujuan, kebutuhan, dan penggunaan komunikasi. Teknologi untuk berkomunikasi dengan khalayak. Bentuk organisasi yang menyediakan keahlian seta mengatur produksi dan distribusi. Bentuk peraturan dan kontrol.

Keempat elemen di atas tidak memiliki hubungan yang kaku antara satu elemen dengan elemen lainnya, tetapi mereka sangat bergantung pada keadaan waktu dan tempat (McQuail, 2011: 27). Selain itu, sebuah teknologi komunikasi diterapkan karena adanya penggunaan dan kebutuhan tertentu. Terdapat berbagai macam media massa berdasarkan teknologi serta bentuk bahannya.

\section{Media Cetak Surat Kabar}

Kemunculan surat kabar awalnya secara berkala dengan bentuk komersial (dijual untuk umum) serta karakternya yang terbuka. Surat kabar digunakan untuk penyebaran informasi, iklan, isu pengalihan, serta gosip. Surat kabar atau koran telah dianggap sebagai suatu pembaruan yang lebih berinovasi serta lebih baik dari buku yang hanya dicetak, karena adanya penemuan bentuk literatur, sosial, dan budaya baru (McQuail, 2011: 30). Surat kabar sebagai media dan lembaga: Aspek media, kemunculan surat kabar secara berkala dan sering, teknologi menggunakan percetakan, isi dalam koran sesuai dengan tema yang ditentukan, Pembacanya individu maupun kelompok, aspek kelembagaan. Perkotaan adalah karakteristik khalayaknya; lebih bebas, masih dalam ranah publik, danomersial (dijual untuk umum)

Koran merupakan media massa paling utama yang memberikan informasi dan berita dalam bentuk cetakan kepada seluruh khalayak atau pembacanya. Kredibilitas serta keakuratan pada sebuah berita di koran sangatlah terpercaya dan tidak diragukan lagi, hal ini lah yang membuat koran 
masih diminati pembacanya sampai saat ini. Selain itu, banyaknya media baru atau media online yang terus berkembang pesat saat ini masih belum dapat menyaingi kedalaman berita dan informasi yang dimiliki oleh koran (Vivian, 2008: 71).

Meski media online semakin banyak diakses oleh sebagian besar masyarakat karena kecepatan pada penayangan beritanya, namun media cetak seperti surat kabar yang masih dikenal oleh masyarakat sebagai media yang memberikan pemberitaan maupun informasi secara mendalam (Budyatma, 2014: 75). Berita dan informasi yang disajikan pada koran memiliki berbagai unsur kebaruan walaupun dalam penyebarannya membutuhkan waktu satu hari untuk percetakan. Pada setiap berita yang disajikan dalam koran selalu menginformasikan perkembangan yang tengah terjadi di masyarakat. Ini lah hal yang menjadikan koran mempunyai berita yang khas dan dekat bagi masyarakat (Santana, 2017: 167). Masyarakat saat ini yang masih mengkonsumsi koran sebagai media informasinya rata-rata yang berumur 20 tahun keatas. Sedangkan untuk remaja atau biasa yang disebut millenial lebih nyaman mendapatkan berita maupun informasi melalui media online. Banyaknya pembaca yang lebih memilih media online karena kenyamanan serta kepraktisan dalam mengaksesnya, media online mengandalkan kecepatan penayangan dalam memberitakan kejadian atau peristiwa yang baru saja terjadi yang membuat pembacanya terpenuhi akan kecepatan informasi (Sambo \& Yusuf, 2017: 6-7).

\section{New Media: Media Online}

Media baru atau media online adalah suatu media yang saling terhubung akses antara khalayak sebagai penerima pesan dan komunikator sebagai pengirim pesan. Karakter dari media baru itu sendiri adalah terbuka, serta bisa diakses di manapun, kapanpun, dan oleh siapapun. Adapun kemunculan dari new media membuat media lama seperti surat kabar menjadi usang atau tidak banyak diminati lagi (McQuail, 2011: 42). Berbagai macam perangkat dan bentuk teknologi baru sebagai alat komunikasi dalam bentuk digitalisasi serta mencakup ketersediaannya yang sangat luas dan beragam lah yang menyebabkan keberadaan media online memiliki dampak terhadap media massa tradisional seperti surat kabar (McQuail, 2011: 148). Dampak yang sangat jelas terjadi saat ini antara lain banyaknya pembaca koran beralih ke platform digital karena lebih praktis mendapatkan berita dan informasi kapanpun dan di manapun mereka berada, tanpa harus membawa beberapa lembar surat kabar dan tanpa harus mengeluarkan uang untuk membeli surat kabar.

\section{METODE}

Penelitian ini menggunakan pendekatan kualitatif, karena dalam penelitian ini membutuhkan pemahaman yang lebih detail mengenai permasalahan yang terjadi pada surat kabar Radar Depok dalam membuat strategi untuk mempertahankan eksistensinya serta upayanya bersaing di industri media. Data yang dibutuhkan untuk menjawab permasalahan pada penelitian ini harus mendalam sehingga memakai pendekatan kualitatif. Pada penelitian ini peneliti menggunakan 2 teknik pengumpulan data, yaitu: wawancara dan dokumentasi. Sementara unit analisis dalam penelitian ini adalah organisasi, dengan fokus pada pengelolaannya dalam mempertahankan eksistensi, sehingga data penelitiannya adalah:

1. Redaktur pelaksana Radar Depok sebagai narasumber utama, karena redaktur pelaksana sebagai orang yang membuat perencanaan isi konten pada setiap pemberitaan dan bertanggungjawab pada rubrik yang dibuat.

2. Jurnalis senior Atmakusumah Astraatmadja sebagai narasumber ahli, karena sebagai orang yang berpengaruh pada perkembangan media di Indonesia khususnya media cetak.

3. Dokumentasi, pada penelitian ini menggunakan dokumen-dokumen perusahaan untuk memperkuat hasil penelitian.

\section{HASIL DAN PEMBAHASAN}

Surat kabar saat ini masih dipertanyakan eksistensinya terkait dengan banyaknya surat kabar yang mengalami pemerosotan jumlah oplah penjualan. Faktor yang menyebabkan media cetak kondisinya seperti sekarang ini adalah karena perkembangan teknologi di mana semakin banyak munculnya media-media baru atau biasa disebut media online. Atmakusumah menambahkan bahwa penurunan oplah yang terjadi pada surat kabar saat ini dikarenakan banyak masyarakat beralih mengkonsumsi media online. Semakin menurunnya minat pembaca koran berpengaruh pada menurunnya pengiklan yang mengiklankan produknya di koran. Inilah salah satu penyebab media cetak banyak yang tutup karena hantaman ekonomi di mana tidak adanya lagi pemasukan. (wawancara dengan Atmakusumah di Jakarta, 2019) 
Menurut Atmakusumah sekarang ini banyak pengarahan diberbagai kota untuk generasi remaja saat ini atau biasa disebut millenial untuk meningkatkan minat bacanya. Pengarahan meningkatkan minat baca ini juga bertujuan agar generasi remaja tertarik untuk mendapatkan informasi melalui koran. Tujuan inilah yang nantinya akan membuat koran kedepannya masih memiliki pembaca serta tidak membuat media cetak seperti koran ini akan benar-benar mati seperti yang sudah diramalkan oleh para ahli. Setelah ditelaah pada temuan ini dengan dapatnya data-data di lapangan, Fahmi mengatakan bahwa pada surat kabar Radar Depok medianya tidak terlalu fokus pada ancaman dari berkembangnya media online. Bagi Radar Depok pengaruh dari media online sangat kecil sekali dan tidak terlalu dipermasalahkan. Jika temuan ini dikaitkan dengan konsep strategi media massa dalam merumuskan strategi, temuan ini jelas tidak sama persis dengan yang ada di mana harusnya setiap perusahaan harus mengidentifikasi ancaman dari tren yang ada dan persaingan teknologi baru yang merugikan (David, 2011: 120).

Menurut Atmakusumah banyaknya pembaca yang beralih ke media online karena kepraktisan. Tidak perlu membeli sebuah koran, tidak perlu membawa koran yang berisi beberapa halaman yang lumayan besar, dan lainnya. Atmakusumah menambahkan saat ia mengakses media online ia hanya mengakses media online yang sudah terverifikasi oleh dewan pers, agar terhindarnya dari pemberitaan hoax yang sudah banyak beredar sekarang ini. Media online yang belum terverifikasi sudah banyak yang tidak mementingkan keakuratan beritanya, melainkan lebih mengutamakan kecepatan tayangnya. (wawancara dengan Atmakusumah di Jakarta, 2019)

Berkembangnya media online tidak menjadi penghambat bagi Radar Depok tetap megeksistensikan medianya dan bersaing di industri media, walaupun Radar Depok mengakui bahwa media cetak sudah mulai tergerus dengan adanya online. Hal ini karena Radar Depok sebagai koran lokal dan mempunyai segmen pasarnya tersendiri di mana surat kabar ini pun sudah memiliki pelanggan tetap. Bagi Radar Depok saat ini lebih mengutamakan fokus dan membuat strategi untuk menjaga kepercayaan pelanggan tetapnya agar tidak berkurang, serta untuk menarik pembaca lainnya agar membaca koran Radar Depok. Di Depok, media cetak seperti koran masih dipegang jadi tidak ada yang perlu dikhawatirkan dari berkembangnya media online bagi Radar Depok.
Menurut Atmakusumah ramalan media cetak akan mati sudah ada sejak munculnya radio, tetapi nyatanya saat ini hal itu tidak sepenuhnya terjadi. Beberapa media cetak ada yang sudah mulai tutup karena belum tentu akibat dari adanya media online saja, melainkan bisa dari manajemen perusahaan masing-masing. Atmakusumah menambahkan bahwa media seperti Radar Depok yang termasuk dalam Jawa Pos Group tidak mudah untuk menutup media cetaknya karena sampai saat ini eksistensinya masih ada di warga Depok. (wawancara dengan Atmakusumah di Jakarta, 2019)

Minat pembaca Radar Depok masih ada karena tergantung isu dan pemberitaannya. Pemberitaan Radar Depok menyajikan 95\% isi konten tentang segala cakupan yang ada di wilayah Depok, selebihnya adalah berita atau informasi nasional yang diambil dari Jawa Pos. Menurut Fahmi Radar Depok selalu ditunggu-tunggu pembaca setiap kali terbit. Radar Depok menyajikan pemberitaan secara continue di mana dalam memberitakan sebuah kejadian atau peristiwa tidak memberitakannya hanya sekali saja, melainkan isu kejadian tersebut diangkat terus oleh Radar Depok sampai tuntas. Cara permberitaan seperti inilah yang membuat masyarakat selalu menunggu koran dari Radar Depok. Isi konten pada Radar Depok sebagai surat kabar lokal melebihi dari yang seharusnya di mana surat kabal lokal harusnya hanya berisi $80 \%$ dalam membahas informasi dari wilayah itu sendiri.

Radar Depok menyajikan isu buatan sendiri di mana isu nasional dijadikan sebagai isu lokal. Salah satu ini pula yang membuat koran Radar Depok tetap diminati oleh masyarakat Depok karena pemberitaan dan informasinya yang sangat berkaitan sebagai masyarakat Depok. Dari pemberitaan yang disajikan ini dapat membuat warga Depok khususnya menjadi mengikuti pemberitaan pada koran ini. Dalam Radar Depok terdapat isi berbagai macam konten dan hampir semuanya ada seperti pendidikan, politik, hiburan, wisata, ekonomi.

Walaupun sangat kecil pengaruh dan ancaman dari adanya media online, Radar Depok tetap mempunyai cara dan strategi agar surat kabarnya tetap memiliki eksistensi di kalangan masyarakat Depok. Dalam menyajikan berita, Radar Depok selalu mengingikan beritanya uptodate. Selain itu pada koran Radar Depok terdapat angle pemberitaan yang beda dari koran lainnya yang membuat Radar Depok lebih unggul dari koran lokal lainnya. Sedangkan menurut Atmakusumah, strategi utama yang harus 
dilakukan oleh Radar Depok untuk mempertahankan eksistensinya adalah memperluas perusahaannya seperti mendirikan siaran radio dan siaran televisi, tetapi media cetak pada Radar Depok harus tetap juga dipertahankan.

Strategi pertama yang dilakukan oleh Radar Depok adalah memodifikasi produknya. Modifikasi pada hal ini adalah membuat inovasi terbaru pada sajian berita di dalam surat kabar. Dalam hal ini Inovasi-inovasi dikeluarkan oleh Radar Depok demi menjadikan koran tersebut tetap enak dibaca dan meningkatkan jumlah minat pembacanya. Dalam memodifikasi produknya Radar Depok melakukan perubahan setiap tahunnya. Perubahan tersebut yaitu berupa memvisualisasikan tampilan di dalamnya, seperti judul rubrik yang dibuat lebih menarik dari sebelumnya serta adanya rubrik-rubrik baru apabila sedang ada moment tertentu disetiap tahunnya. Selain itu juga adanya pembagian wilayah pada koran Radar Depok di mana wilayah Depok dibagi menjadi dua untuk memudahkan pembaca yang ingin mengetahui informasi atau pemberitaan sesuai wilayahnya masing-masing. Jadi dapat dipastikan bahwa setiap tahunnya Radar Depok memiliki perubahan visual yang berbeda dari sebelumnya. Inovasi ini dibuat agar pembaca serta pelanggan tetapnya tidak bosan dan tetap tertarik untuk membaca koran Radar Depok.

Menurut Atmakusumah untuk tetap memajukan surat kabarnya Radar Depok harus tetap konsisten untuk menyajikan berita dan informasi yang lebih komprehensif, dan selalu menampilkan banyak foto yang menarik dari angle yang berbeda. Radar Depok juga memiliki ciri khas di mana pada pemberitaannya bahasa dan judulnya dibuat menjadi nyeleneh agar menarik hati para pembaca. Atmakusumah menambahkan bahwa saat ini masih banyak pemasang iklan yang lebih percaya diri memuat iklannya di media cetak dibanding media online. (wawancara dengan Atmakusumah di Jakarta, 2019)

Strategi kedua yaitu membuat produk baru di mana produk baru di sini diartikan sebagai membuat platform online. Memang faktanya Radar Depok mengakui bahwa media online lebih menguntungkan dalam segi ekonomi karena tidak perlu memerlukan biaya produksi cetak. Radar Depok menjalankan media onlinenya sudah dari 2016, walaupun begitu tetap yang menjadi fokus Radar Depok adalah surat kabarnya. Adapun dengan seiring berjalannya waktu media online Radar Depok menjadi yang terdepan dalam cakupan wilayah Depok di mana media online
Radar Depok sebagai media online lokal yang paling banyak dibaca.

Ada kekurangan dari media online Radar Depok di mana dalam menayangkan beritanya lebih telat di mana harusnya keunggulan media online adalah kecepatan beritanya. Walaupun telat dalam penayangannya, media online Radar Depok ini rangenya berada yang paling tinggi dalam cakupan lokal (data dari website alexa). Dengan fakta yang ada, nyatanya media online yang dimiliki oleh Radar Depok tidak memenuhi karakteristik dari media online lainnya yang selalu realtime dalam menayangkan berita.

Atmakusumah mengkhawatirkan media cetak yang juga mengembangkan media onlinenya. Dia khawatir kalau saat proses pembuatan di media online, tidak dilakukan secara ketat seperti bekerja saat proses pembuatan berita pada media cetak. Hal ini tentunya sudah banyak terjadi pada media online di Indonesia di mana dampaknya adalah muncul berbagai berita hoax yang belum tentu kebenarannya. Menurut Atmakusumah, jangan menjadikan kebebasan pers saat ini menjadi kebablasan serta tidak ada batasnya. Jadi media online pun harus mengutamakan kode etik jurnalistik sebagaimana yang sudah ada dan dilakukan pada media cetak.

Pelaksanaan strategi yang telah dirancang oleh Radar Depok sudah berjalan dengan efektif secara keseluruhan. Menurut Fahmi, strategi yang dirancang dapat berjalan sejauh ini secara efektif karena Radar Depok melakukan rapat redaksi tiga kali dalam satu minggu, yang membuat perusahaan ini terus mengevaluasi untuk lebih maju lagi kedepannya. Walaupun adanya hal-hal kecil yang menghambat seperti kurangnya pemberitaan yang didapat oleh wartawan saat di lapangan tetapi masalah tersebut dapat diatasi dengan turunnya redaktur agar bisa melengkapinya dan menjadikan pemberitaannya komprehensif dan bagus. Selalu fokus pada strategi yang telah dibuat membuat Radar Depok pun dapat menghasilkan pencapaian yang diinginkan. Pencapaian yang didapat oleh Radar Depok terkait dengan berjalannya pelaksanaan strategi serta strategi itu dibilang sudah efektif memang sudah terbukti. Radar Depok memenangkan kejuaraan liputan yang diadakan oleh Radar Bogor Group di mana di dalamnya terdapat tujuh anak perusahaan lainnya. 
Beberapa strategi yang digunakan oleh Radar Depok memiliki persamaan dengan penelitian yang dilakukan oleh Naufal Hadi (2018) dan Sholahuddin (2013). Peneliti menggunakan dua penelitian tersebut sebagai acuan dari penelitian ini. Penelitian yang dilakukan oleh keuda peneliti tersebut terdapat adanya beberapa strategi yang dilakukan untuk tetap mempertahankan eksistensi serta dapat bersaing di industri media khususnya media online. Pertama penelitian Naufal, menurut yang ada pada penelitian tersebut strategi pertama yang dilakukannya adalah membuat rubrik-rubrik baru. Di mana strategi tersebut sama halnya dengan yang diterapkan oleh Radar Depok di mana Radar Depok memodifikasi produknya dengan menginovasikan rubrik baru. Rubrik baru yang disajikan oleh Radar Depok setiap tahunnya tergantung dengan moment yang ada, misalnya untuk saat ini seperti adanya rubrik Ramadan Depok.

Kedua, persamaan pada penelitian dari Sholahuddin. Pada penelitian tersebut menggunakan strategi yaitu membuat produk baru dalam bentuk media online. Di mana dalam hal ini adanya persamaan yaitu diterapkannya produk baru oleh Radar Depok dengan membuat media online. Dibuatnya media online karena untuk mengantisipasi terpuruknya media cetak seperti surat kabar. Dengan media online pula tidak dapat dipungkiri bahwa media online lebih menguntungkan. Dilihat dari keuntungan pengeluaran dan pendapatannya, memang media online lebih unggul karena tidak memerlukan biaya untuk produksi cetak.

Radar Depok masih memiliki eksistensi di wilayah Depok karena media ini sudah terverifikasi oleh dewan pers. Selain itu Radar Depok merupakan koran harian yang selalu terbit setiap hari, dan tidak pernah tidak terbit. Walaupun masih memiliki banyak minat pembaca, Radar Depok tetap mempertahankan eksistensinya dengan strategistrategi yang sudah dibuat dan terus dikembangkan agar tetap menjadi koran nomor satu di kota Depok. Peluang serta eksistensi masih dimiliki oleh Radar Depok ditengah-tengah perkembangan media online. Atmakusumah menambahkan bahwa Radar Depok sudah membuat strategi tetap bertahan di mana pada koran itu sudah dilengkapi gambar-gambar yang menarik pembaca dan membuat layout yang dapat menandingi media online.

Strategi yang telah dibuat oleh Radar Depok terbukti bahwa masih adanya peluang untuk tetap bertahan bagi surat kabar Radar Depok. Berita dan informasi yang disajikan pada surat kabar ini tidak didapatkan pada media online. Kelebihan dari media cetak seperti kelengkapan berita, kedalaman berita, banyaknya foto yang disajikan, dan inovasi lainnya. Masih bertahannya media cetak saat ini karena masih adanya minat masyarakat untuk mendapatkan sebuah informasi secara mendalam. Menurut Atmakusumah keuntungan menggunakan media cetak yaitu dapat didokumentasikan. Berita atau informasi yang menarik menurutnya lah yang dipertahankan dan disimpan.

Fakta yang ada, surat kabar Radar Depok memiliki 16 halaman di mana akan tetap selamanya seperti itu menurut Fahmi. Walaupun sudah tergerus tetapi surat kabar akan tetap ada pada karakteristiknya di mana tetap menyajikan pemberitaan yang lengkap dan dilengkapi banyak gambar-gambar. Hal ini tentunya bertolak belakang dengan pernyataan yang diungkapkan oleh Atmakusumah, di mana surat kabar nantinya akan semakin kecil dan bisa menjadi jurnal.

Radar Depok menyatakan sebagai perusahaan media cetak di mana memiliki kelelahan mendapatkan pemasukan untuk pembayaran cetak. Masalah tersebut terus masih diperjuangkan dengan cara mendapatkan lebih banyak iklan. Di lain hal Radar Depok masih akan tetap bertahan karena masyarakat sekitar selalu mengandalkan Radar Depok sebagai media penyebaran informasi di wilayahnya.

Keterpurukan pada media cetak belum diketahui kapan tapi bisa saja terjadi karena manajemen kantornya sendiri. Selain mengandalkan iklan untuk proses produksi cetaknya, Radar Depok disubsidikan oleh Grup Radar Bogor. Jadi, bagi Radar Depok pun permasalahan biaya produksi masih dapat ditangani untuk saat ini. Tetap untuk saat ini pun Radar Depok tidak terlalu mempermasalahkan perkembangan media online, dan tidak menganggapnya juga sebagai ancaman. Fokus Radar Depok kedepannya adalah selalu konsisten dalam menyajikan pemberitan dan isu yang menarik serta menginovasikan surat kabarnya agar semakin bertambah minat pembaca Radar Depok.

\section{SIMPULAN}

Strategi Radar Depok untuk mempertahankan eksistensi dan mengantisipasi persaingan di industri media pada dasarnya memiliki dua strategi. Berdasarkan kajian konsep manajemen 
media yang digunakan untuk menghasilkan data penelitian, oplah Radar Depok di tahun 2019 masih tetap stabil yaitu di angka 700 lebih eksemplar perhari. Kestabilan jumlah oplah ini dikarenakan Radar Depok memiliki pelanggan setia dari tahun ke tahun. Iklan yang terdapat di koran ini tidak menentu, bisa hanya terdapat 5 iklan dari 16 halaman dan bisa juga terdapat $10 \mathrm{iklan}$.

Strategi paling utama surat kabar Radar Depok adalah modifikasi produk. Salah satu yang sering Radar Depok lakukan ialah selalu merubah visual yang ada pada korannya seperti merubah tampilan judul rubrik agar lebih menarik dan berbeda dari sebelumnya. Radar Depok juga mengandalkan rubrik-rubrik baru yang dimunculkan hanya pada momen tertentu seperti saat ini adanya rubrik ramadan depok di mana rubrik ini hanya ada satu bulan. Pada koran ini terdapat dua pembagian wilayah di mana untuk memudahkan pembaca yang ingin mengetahui pemberitaan sesuai wilayahnya masing-masing. Radar Depok juga memiliki ciri khas pada pemberitaan, di mana bahasa dan judulnya dibuat menjadi nyeleneh agar menarik hati para pembaca. Strategi kedua Radar Depok memiliki platform online. Media online dibuat karena lebih menguntungkan dalam segi ekonomi karena tidak perlu memerlukan biaya produksi cetak. Surat kabar Radar Depok tetap menjadi fokus walaupun sudah adanya media online. Dalam cakupan wilayah Depok, media Radar Depok tetap menjadi media online lokal yang terdepan dan terpercaya Kekurangan dari media online Radar Depok di mana dalam menayangkan beritanya lebih lambat, walaupun lebih lambat dalam penayangannya media online ini tetap berada yang paling tinggi diakses dalam cakupan lokal.

Saran akademis yang dapat peneliti berikan kepada pembaca yang mengambil penelitian sejenis yaitu dalam mengangkat tema penelitian ini sebaiknya mengambil objek penelitian pada media nasional karena akan berbeda hasil penelitiannya dari sebelum-sebelumnya dan mendapatkan strategi-strategi baru yang ada pada media tersebut untuk mengantisipasi surat kabar di tengahtengah berkembangnya media online. Selain itu kajian penelitian ini menarik untuk diteliti karena fenomena ini ada di tengah masyarakat yang kebanyakan sudah menggunakan gadget dalam mendapatkan informasinya. Saran praktis yang dapat peneliti berikan kepada pembaca yaitu hasil dari penelitian ini dapat dijadikan kajian yang positif sehingga peneliti yang mengangkat penelitian sejenis dapat meningkatkan minat bacanya pada koran lagi. Selain itu dalam penelitian selanjutnya akan jauh lebih mendalam tentang strategi pada surat kabar dalam mengantisipasi media online.

\section{DAFTAR PUSTAKA}

Budyatma, M. (2014). Jurnalistik teori \& Praktik. Bandung: PT. Remaja Rosdakarya.

Cangara, H. (2010). Pengantar Ilmu Komunikasi. Jakarta: PT. Raja Grafindo Persada.

David, F. R. (2011). Manajemen Strategis. Jakarta: Salemba Empat.

Heizer, J., Render, B. (2009). Manajemen Operasi. Jakarta: Salemba Empat.

Kotler, P., Keller, K. L. (2011). Manajemen Pemasaran, Edisi 13 Jilid 1 dan 2, Alih Bahasa: Bob Sabran. Jakarta: Erlangga.

McQuail, D. (2011). Teori Komunikasi Massa. Jakarta: Salemba Humanika.

Morissan, M. A. (2008). Manajemen Media Penyiaran: Strategi Mengelola Radio \& Televisi. Jakarta: Kencana Prenada Media Group.

Pearce II, J. A., Robinson, R. B. (2008). Manajemen Strategis edisi 10. Jakarta: Salemba Empat.

Rangkuti, F. (2013). Analisis SWOT: Teknik Membedah Kasus Bisnis. Jakarta: PT Gramedia Pustaka Utama.

Sambo, M., Yusuf, J. (2017). Pengantar Jurnalisme Multiplatform. Depok: Prenada Media Group,

Santana, K. S. (2017). Jurnalisme Kontemporer edisi kedua. Jakarta: Yayasan Pustaka Obor Indonesia.

Sholahuddin. (2013). Strategi Pengembangan Produk di Industri Media Cetak di Indonesia (Bertahan di Tengah Persaingan dengan Media Online). Vol. 17, No. 1, 9-17.

Tamburaka, A. (2012). Agenda Setting Media Massa. Jakarta: PT RajaGrafindo Persada.

Terry, G. R., \& Rue, L.W. (2015). Dasar-Dasar Manajemen. Jakarta: PT Bumi Aksara.

Vivian, J. (2008). Teori Komunikasi Massa. Jakarta: Prenada Group. 